\title{
ANALISIS RASIO AKTIVITAS DAN RASIO SOLVABILITAS UNTUK MENGUKUR KINERJA KEUANGAN \\ (Studi kasus pada PT. Gudang Garam, Tbk. Thn. 2013-2017)

\author{
Muslim ${ }^{1)} \&$ Yeni Indri Yani ${ }^{2)}$
}

1,2) dosen universitas pamulang, email : dosen00092@unpam.ac.id

\section{ARTICLES}

INFORMATION

\section{ABSTRACT}

\author{
JURNAL SEKURITAS \\ (Saham, Ekonomi, Keuangan \\ dan Investasi ) \\ Vol.2, No.2, Januari 2019 \\ Halaman : $98-112$ \\ C LPPM \& Prodi Manajemen \\ UNVERSITAS PAMULANG

\section{ISSN (online) : 2581-2777 \\ ISSN (print) : :2581-2696}

\section{Keyword :}

Rasio Aktivitas, Solvabilitas, dan Kinerja Keuangan i

JEL. classification :

C33, G21, G34, N25

\section{Contact Author :}

PRODI MANAJEMEN UNPAM

JL.Surya Kencana No.1 Pamulang

Tangerang Selatan - Banten

Telp. (021) 7412566, Fax (021) 7412491 Email :

jurnalfinance.unpam@gmail.com
Tujuan dari penelitian yang dilakukan adalah untuk megetahui Aktivitas pada PT. Gudang Garam Tbk, untuk mengetahui sovabilitas pada PT. Gudang Garam Tbk, Dan untuk mengetahui rasio Aktivitas dan solvabilitas terhadap Kinerja Keuangan pada PT. Gudang Garam Tbk.

Objek dalam penelitian ini adalah PT. gudang Garam Tbk. yang terdaftar di Bursa Efek Indonesia (BEI). Metode yang digunakan pada penelitian ini adalah metode deskriptif yang bersifat kuantitatif karena penelitian ini berkaitan dengan objek penelitian yaitu pada perubahan dalam kurun waktu tertentu dengan mengumpulkan data dan informasi yang berkaitan dengan tujuan penelitian. Metode analisis data yang digunakan adalah metode analisis rasio. Analisi yang digunakan dalam penelitian ini adalah rasio keuangan yang terdiri dari: Rasio Aktivitas yaitu efesiensi atau efektivitas perusahaan dalam pemanfaatan semua sumber daya atau asset (aktiva) yang dimiliki oleh suatu perusahaan, serta Rasio Solvabilitas yaitu kemampuan perusahaan untuk memenuhi semua kewajibannya baik jangka pendek atau jangka panjang saat perusahaan dilikuidasi (dibubarkan).

Hasil penelitian menunjukkan bahwa kondisi keuangan PT. Gudang Garam Tbk dari tahun 2013 sampai dengan 2017 mengalami fluktuasi setiap tahunnya tetapi sudah dapat memenuhi standard yang dikeluarkan oleh Mentri Keuangan. Analisis rasio aktivitas PT. Gudang Garam Tbk yang terdiri dari Working Capital Turn Over menunjukkan bahwa keadaan perusahaan berdasarkan rasio tersebut kurang sehat, serta Total Assets Turn over kurang sehat. PT. Gudang Garam Tbk dikategorikan "tidak sehat" karena berada dibawah rata-rata industri. Serta analisis solvabilitas menunjukkan bahwa hasilnya belum memenuhi standar industri yang dikeluarkan oleh mentri keuangan. 


\section{A. Pendahuluan}

Dengan perkembangan teknologi yang semakin meningkat serta makin banyak jumlah perusahaan-perusahaan sejenis yang muncul, maka persoalan manajemen pun akan semakin komplek dan persaingan antara perusahaan pun semakin ketat.Untuk menghadapi persaingan yang sangat ketat, perusahaan tentu saja perlu melaksanakan fungsi manajemen yang diantarnya meliputi perencanaan, pengorganisasian dan pengendalian secara baik sehingga tujuan perusahaan dapat tercapai.

Dengan ini semakin tingginya tingkat persaingan bisnis di Indonesia telah memaksa perusahaan-perusahaan di Indonesia untuk sebisa mungkin mempertahankan kelangsungan usahanya. Dengan keadaan seperti itu, sehingga memicu perusahaan untuk kerja keras dalam menghasilkan laba yang menjadi tujuan utama setiap usaha. Selain dengan melakukan efisiensi terhadap biaya-biaya produksi, perusahaan juga biasanya menggunakan fasilitas kredit, baik kredit modal kerja atau kredit pembelian bahan baku. Hal ini bertujuan untuk menjaga eksistensi dan agar mampu bersaing dengan perusahaan- perusahaan sejenis. Perusahaan dalam perkembangannya mempunyai tujuan yang tidak jauh berbeda antara perusahaan satu dengan yang lainnya, yaitu laba (profit), pertumbuhan (growth), kelangsungan hidup perusahaan (survive), dan tujuan tersebut harus dicapai oleh semua pihak didalam perusahaan. Hal tersebut dapat terwujud apabila semua unsur dalam perusahaan bersinergi dengan baik. Baik itu berupa sumber daya modal maupun sumber daya manusianya. Kinerja yang baik dari sumber daya manusia yang mengelola sumberdaya modal perusahaan sangat penting.

Untuk melihat keberhasilan kinerja keuangan suatu perusahaan antara lain dengan melihat laporan keuangan tahunan yang telah dikeluarkan oleh perusahaan yang terdiri dari neraca, laporan laba rugi, laporan laba rugi ditahan dan cash flow. Laporan keuangan melaporkan aktivitas yang sudah dilakukan perusahaan dalam periode tertentu. Aktivitas yang sudah dilakukan dituangkan berbentuk angka-angka, baik dalam mata uang rupiah maupun dalam mata uang asing.

PT. Gudang Garam, Tbk adalah produsen rokok kretek terkemuka yang identik dengan Indonesia yang merupakan salah satu sentra utama perdagangan rempah di dunia. Dengan total penduduk sekitar 250 juta jiwa, Indonesia merupakan pasar konsumen yang besar dan beragam dengan persentase perokok dewasa yang signifikan, diperkirakan 67\% laki-laki dewasa di Indonesia adalah perokok. Berdasarkan riset pasar Nielsen, pada akhir tahun 2016 Gudang Garam memiliki pangsa pasar rokok dalam negeri sekitar 250 juta jiwa, Indonesia merupakan pasar konsumen yang besar dan beragam dengan persentase perokok dewasa yang signifikan, diperkirakan 67\% laki-laki dewasa di Indonesia adalah perokok. Berdasarkan riset pasar Nielsen, pada akhir tahun 2016 Gudang Garam memiliki pangsa pasar rokok dalam negeri sekitar 20,8\% dengan produk-produk yang sudah dikenal luas oleh masyarakat di seluruh Nusantara. Gudang Garam menyediakan lapangan kerja bagi 35.900 orang yang terlibat dalam produksi rokok, pemasaran dan distribusi di akhir tahun 2016. Perusahaan juga memilliki 67 kantor area dengan 279 
titik distribusi di seluruh Indonesia dan armada penjualan lebih dari 7.000 kendaraan, termasuk sepeda motor untuk melayani pasar.

Kesejahteraan karyawan menjadi perhatian utama, dari standar keselamatan

kerja dan penyediaan fasilitas kesehatan hingga pelatihan kepemimpinan, manajemen, administrasi dan ketrampilan teknik, yang diselenggarakan di dalam maupun di luar perusahaan.

Berdasarkan uraian diatas maka penulis tertarik untuk menganalisis kinerja keuangan berdasarkan rasio keuangan yaitu rasio Aktivitas dan rasio Solvabilitas (Leverage) pada tahun 2013 sampai dengan tahun 2017. Dengan demikian dalam penulisan ini penulis ingin mengkaji lebih jauh lagi dengan mengadakan penelitian dengan judul: "ANALISIS RASIO AKTIVITAS DAN RASIO SOLVABILITAS UNTUK MENGUKUR KINERJA KEUANGAN (Studi kasus PT. Gudang Garam, Tbk ) pada tahun 2013-2017."

\section{B. Identifikasi Masalah}

Berdasarkan pada pembahasan latar belakang masalah diatas, ditemukan berbagai permasalahan yang berkaitan dengan fenomena yang diangkat serta kajian teroritis, empiris dan normatif berikut identifikasi permasalahan tersebut:

1. Working Capital Turn Over pada PT. Gudang Garam, Tbk mengalami

2. Flukturatif pada tahun 2013-2017.

3. Total Assets Turn Over pada PT. Gudang Garam, Tbk mengalami

4. Flukturatif pada tahun 2013-2017.

5. Debt to Assets Ratio pada PT. Gudang garam, Tbk tahun 2013-2017 yang belum stabil dikarenakan mengalami Flukturatif sehingga pada tahun 2017 yakni 37\%.

6. Debt to Equity Ratio pada PT. Gudang Garam, Tbk tahun 2013-2018 yang belum stabil dikarenakan hutang jangka panjang lebih besar dari modal sendiri.

\section{Batasan Masalah}

Setelah dikemukakan sedikitnya permasalahan sebagaimana dalam identifikasi masalah, namun penulis membatasi permasalahan-permasalahan yang memiliki relefansi dengan judul yang diangkat. Hal tersebut, dalam rangka konsistensi atas apa yang penulis kemukakan dan bertujuan penelitian ini sejalan dengan kelemahan. Serta diharapkan hasil yang diperoleh lebih terarah dan sesuai dengan yang diharapkan. Berikut ini batasan masalah yang akan dikaji:

1. Menganalisis Rasio Aktivitas dengan menghitung Total Assets Turnover pada PT. Gudang Garam, Tbk tahun 2013-2017 yang mengalami Peningkatan kembali pada tahun 2017 menjadi 0,27 kali.

2. Menganalisis Rasio Solvabilitas dengan menghitung Debt to Assets Ratio pada PT. Gudang garam, Tbk tahun 2013-2016 yang belum stabil dikarenakan mengalami penurunan dari tahun 2016-2017 menjadi 37\%.

3. Menganalisis Rasio Aktivitas dan Rasio Solvabilitas terhadap kinerja keuangan PT. Gudang Garam, Tbk pada tahun 2013-2017. 


\section{Rumusan Masalah}

Sesuai dengan pembahasan teori dan kajian empiris kemudian diketahui jelasnya permasalahan-permaslahan dan kemudian dibatasi permasalahan tersebut makan, penulis dapat merumuskan permasalahan yang akan dibahas.

1. Bagaimana rasio Aktivitas pada PT. Gudang Garam, Tbk tahun 2013-2017 ?

2. Bagaimana rasio Solvabilitas pada PT. Gudang Garam, Tbk tahun 2013-2017?

3. Bagaimana analisis rasio Aktivitas dan rasio Solvabilitas untuk mengukur kinerja keuangan pada PT. Gudang Garam, Tbk tahun 2013-2017?

\section{E. Manfaat Penelitian}

Penelitian ini diharapkan dapat bermanfaat untuk semua pihak baik secara teoritis atau akademis maupun secara praktis. Hasil penelitian ini diharapkan dapat digunakan sebagai bahan pertimbangan untuk lebih meningkatkan kinerja keuangan serta dapat menarik kesimpulan dari hasil penelitian ini, dan dapat dijadikan sebagai salah satu pedoman dalam pengambilan keputusan strategis perusahaan. Serta sebagai refrensi bagi yang tertarik dengan penilaian ini sehingga dijadikan kajian untuk penelitian sejenis.

\section{F. Kerangka Berfikir}

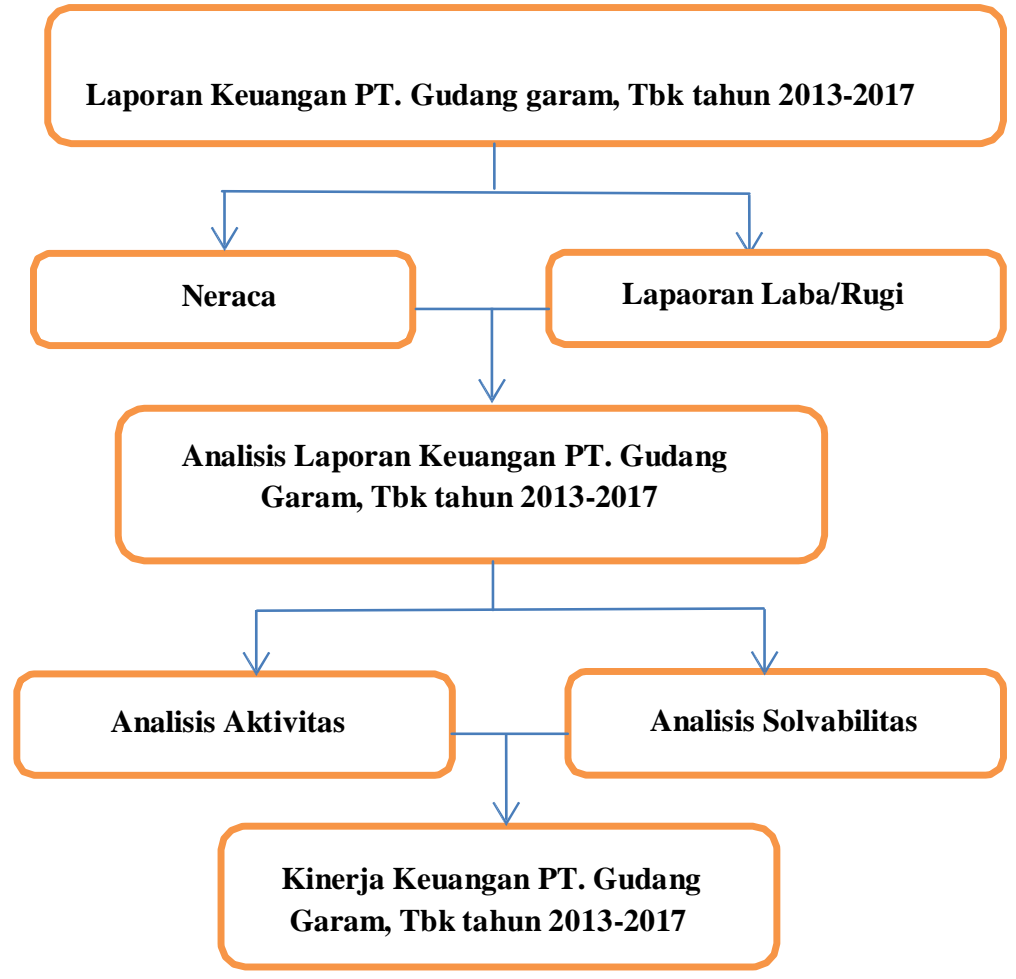

Gambar 1.1

Kerangka Berfikir 


\section{TINJAUAN PUSTAKA}

\section{A. Analisis Laporan Keuangan}

Salah satu tugas penting manajemen atau investor setelah akhir tahun ialah menganalisis laporan keuangan perusahaan. Analisis ini didasarkan pada laporan keuangan yang sudah disusun. Sebaiknya laporan keuangan itu adalah laporan yang diyakini kewajarannya.

Meurut sofyan syafri Harap (2015:190) analisis laporan keuangan adalag menguraikan pos-pos laporan keuangan menjadi unit informasi yang lebih kecil dan melihat hubungan yang bersifat signifikan atau yang mempunyai makna antara satu dengan yang lain antara data kuantitatif maupun data non-kuantitatif dengan tujuan untuk mengetahui kondisi keuangan lebih dalam yang sangat penting dalam proses menghasilkan keputusan yang tepat.

\section{B. Rasio Aktivitas}

Salah satu rasio yang digunakan untuk mengetahui keefektifan perusahaan dalam mengelola aktiva adalah rasio aktivitas.

Aktivitas dinyatakan sebagai perbandingan penjualan dengan berbagi elemen aktiva. Elemen aktiva sebagai penggunaan dana seharusnya bias dikendalikan agar bias dimanfaatkan secara optimal. Semakin efektif dalam memanfaatkan dana semakin cepat perputaran dana tersebut, karena rasio aktivitas umumnya diukur dari perputaran masing-masing elemen aktiva.

Menurut Kasmir (2015:172) merupakan rasio yang digunakan untuk mengukur efektivitas perusahaan dalam menggunakan aktiva yang dimilikinya. Atau dapat pula dikatakan rasio ini digunakan untuk mengukur tingkat efesiensi (efektivitas) pemanfaatan sumber daya perusahaan.

Menurut Hery (2017:178) pengukuran rasio aktivitas dilakukan dengan cara membandingkan besarnya tingkat penjualan dengan piutang usaha, persedian barang dagang, modal kerja (asset lancar), asset tetap, maupun total asset. Mencari tahu kemampuan manajemen dalam menggunakan dan mengoptimalkan asset yang dimiliki merupakan tujuan utama dari rasio aktivitas

\section{Rasio Solvabilitas}

Adapun Rasio solvabilitas atau Leverage yang merupakan rasio yang digunakan untuk mengukur sejauh mana aktivas perusahaan dibiayai dengan hutang. Artinya berapa besar beban utang yang ditanggung perusahaan dibandingkan dengan aktivanya.

Menurut Kasmir (2010:112), rasio solvabilitas atau leverage ratio, merupakan rasio yang digunakan untuk mengukur sejauh mana aktiva perusahaan dibiayai dengan hutang. Artinya seberapa besar beban hutang yang ditanggung perusahaan dibandingkan dengan aktivanya. Dalam arti luas dikatakan bahwa rasio solvabilitas digunakan untuk mengukur kemampuan perusahaan untuk membayar seluruh kewajiban baik jangka pendek maupun jangka panjang apabila perusahaan dibubarkan (dilikuidasi). 


\section{Kinerja Keuangan}

Kinerja (performance) adalah hasil kinerja yang dapat dicapai oleh seseorang atau kelompok orang dalam suatu organisasi susai dengan wewenang dan tanggung jawab masing-masing dalam rangka upaya mencapai tujuan organisasi secara legal, tidak melanggar hokum dan sesuai dengan norma maupun etika.

Menurut Irham Fahmi (2011:142) kinerja keuangan adalah salah suatu analisis yang dilakukan untuk melihat sejauh mana suatu perusahaan telah melaksanakan dengan menggunakan aturan-aturan pelaksanaan keuangan secara baik dan benar. Seperti dengan membuat suatu laporan keuangan yang telah memenuhi standard an ketentuan dalam SAK (Standar Akuntansi Keuangan) atau GAP (General Acepted Accounting Principle) dan lainnya, secara umum, kinerja keuangan dapat didefinisikan sebagai prestasi kinerja yang dapat didefinisikan sebagai prestasi kinerja yang dapat dicapai oleh suatu perusahaan selama jangka waktu tertentu. Prestasi yang dimaksud adalah efektifitas operasional perusahaan baik

dilihat dari segi ekonomi maupun manajemennya. Untuk mengetahui prestasi yang berhasil dicapai oleh perusahaan, maka kita harus menilai kinerjanya.

Menurut Sugiyono (2009:65) dari segi manajemen keuangan, perusahaan dikatakan mampunyai kinerja keuangan yang baik atau tidak, dapat diukur dengan:

a. Kemampuan perusahaan unruk memenuhi kewajiban (utang) yang akan jatuh tempo (liquidity).

b. Kemampuan perusahaan untuk menyusun stuktur pendanaan, yaitu perbandingan antara utang dan modal (leverage).

c. Kemampuan perusahaan untuk memperoleh keuntungan (profitability).

d. Kemampuan perusahaan untuk berkembang growth), dan

e. Kemampuan perusahaan untuk mengelola asset secara maksimal (activity).

Dari definisi keuangan tersebut dapat disimpulkan bahwa kinerja keuangan merupakan suatu hasil atau gambaran yang dicapai oleh suatu perusahaan dalam mencerminkan prestasi kerja dalam periode tertentu yang dapat dijadikan sebagai acuan untuk dapat mengetahui baik buruknya keadaan keuangan perusahaan tertentu. Untuk mengetahui bagaimana kinerja keuangan perusahaan diperlukan pemeriksaan dan analisis laporan keuangan. Laporan keuangan melaporkan prestasi historis dari suatu perusahaan dan memberikan dasar keberadaan ekonomi perusahaan saat ini dan membuat peramalan untuk masa depan. Laporan keuangan disusun untuk menyediakan informasi keuangan suatu perusahaan kepada pihak-pihak yang berkepentingan sebagai bahan pertimbangan dalam pengambilan keputusan.

\section{METODE PENELITIAN}

Objek penelitian yang dipilih pada penulisan penelitian ini adalah PT. Gudang Garam Tbk. Untuk memperoleh data dan informasi penulis telah melakukan penelitian pada Bursa Efek Indonesia (BEI) yang bertepatan di gedung Bursa Efek Indonesia (BEI) yang berlokasi di Jl. Jendral Sudirman Kav. 52-53 Jakarta 12190.

Untuk memperoleh data dan informasi yang diperlukan dalam penyusunan penelitian ini penulis melkukan selama 3 bulan. Waktu ini digunakan untuk observasi, 
pengumpulan kepustakaan dan pengambilan data. Data yang diambil adalah data untuk tahun 2013-2017.

Penelitian yang dilakukan oleh penulis dalam menyusun penelitian ini bersifat deskriptif kuantitatif, yang artinya memberikan suatu gambaran yang teratur tentang suatu peristiwa serta menguraikan bagaimana hasil dari perhitungan data-data finansial perusahaan dalam bentuk laporan keuangan. Data yang diambil dalam penelitian ini dan penelitian penelitian ini adalah data-data yng terdapat dalam laporan keuangan PT. Gudang Garam Tbk.

Populasi yang digunakan penelitian dalam penelitian ini adalah laporan keuangan yang berupa laporan keuangan (neraca). Serta informasi- informasi yang berkaitan dengan pendirian dan kegiatan usaha perusahaan tersebut.

Sample dalam yang digunakan penelitian ini adalah laporan posisi keuangan(neraa) pada PT Gudang Garam Tbk. Periode 2013-2017.

Metode analisis data yang digunakan dalam penelitian ini adalah metode deskriptif kuantitatif, yaitu dengan melakukan pengolahan data-data finansial perusahaan dalam bentuk laporan keuangan.

Penulis melakukan pendekatan dengan studi kasus. Sedangkan metode yang digunakan dalam penelitian ini adalah metode kuantitatif, merupakan suatu metode dalam penggunaan angka. Mulai dari pengumpulan data, dan penampilan dari hasil.

\section{PEMBAHASAN DAN PENELITIAN}

\section{A. Gambaran Umum Objek Penelitian}

Perusahaan rokok Gudang Garam adalah salah satu industri rokok terkemuka di tanah air yang telah berdiri sejak tahun 1958 di kota Kediri, Jawa Timur. Hingga kini, Gudang Garam sudah terkenal luas baik di dalam negeri maupun mancanegara sebagai penghasil rokok kretek berkualitas tinggi. Produk Gudang Garam bisa ditemukan dalam berbagai variasi, mulai sigaret kretek klobot (SKL), sigaret kretek linting-tangan (SKT), hingga sigaret kretek linting-mesin (SKM). Bagi Anda para penikmat kretek sejati, komitmen kami adalah memberikan pengalaman tak tergantikan dalam menikmati kretek yang terbuat dari bahan pilihan berkualitas tinggi.

Berawal dari industri rumahan, perusahaan kretek Gudang Garam telah tumbuh dan berkembang seiring tata kelola perusahaan yang baik dan berlandaskan pada filosofi Catur Dharma. Nilai-nilai tersebut merupakan panduan kami dalam tata laku dan kinerja perusahaan bagi karyawan, pemegang saham, serta masyarakat luas.

Apa yang dicapai Gudang Garam saat ini tentunya tidak terlepas dari peran penting sang pendiri, Surya Wonowidjojo.

Didirikan pada tahun 2002, PT. Surya Madistrindo adalah perusahaan yang dimiliki oleh PT. Gudang Garam Tbk. untuk menjalankan distribusi produkproduk sigaret Gudang Garam bersama dengan 3 perusahaan distribusi lainnya. Di tahun 2009, SM ditunjuk sebagai distributor tunggal yang memegang kendali strategi distribusi dan field marketing untuk seluruh wilayah Indonesia.

Bermarkas di Jakarta, SM telah tumbuh dan bertransformasi menjadi perusahaan distribusi rokok yang profesional dan modern. Berawal dari beberapa ribu karyawan, kini SM telah didukung oleh sumber daya manusia mencapai 
lebih dari 14 ribu orang yang tersebar pada 12 kantor perwakilan regional dan lebih dari 180 kantor perwakilan area di Indonesia.

\section{B. Pembahasan dan Hasil}

1. Rasio Aktivitas pada PT Gudang Garam Tbk periode 2013-2017.

Untuk membahas mengenai analisis rasio keuangan, maka diperlukan data laporan keuangan berupa neraca dan Laporan Laba Rugi yang digunakan untuk menghitung rasio keuangan.

Berdasarkan laporan posisi keuangan dapat dihitung rasio aktivitas dan rasio solvabilitas PT. Gudang Garam Tbk. Selama 5 tahun terakhir, dimulai dari tahun 2013 sampai dengan tahun 2017.

\section{a. Working Capital Turn Over}

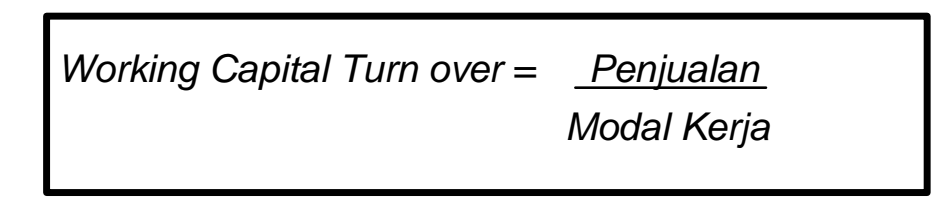

Tabel 4.1

PT. Gudang Garam Tbk

Hasil Perhitungan Working Capital turn Over

Periode 2013-2017

\begin{tabular}{|c|c|c|c|c|c|c|c|}
\hline Tahun & Penjualan & $\begin{array}{c}\text { Aktiva } \\
\text { Lancar }\end{array}$ & $\begin{array}{c}\text { Hutang } \\
\text { Lancar }\end{array}$ & $\begin{array}{c}\text { Working } \\
\text { Capital } \\
\text { TurnOver }\end{array}$ & $\begin{array}{c}\text { Naik } \\
\text { (Turun) }\end{array}$ & $\begin{array}{c}\text { Standar } \\
\text { Industri }\end{array}$ & Keterangan \\
\hline 2013 & 55.436 .954 & 34.604 .461 & 20.094 .580 & 3,82 & - & $<6$ kali & $\begin{array}{c}\text { Kurang } \\
\text { Sehat }\end{array}$ \\
\hline 2014 & 65.185 .850 & 38.532 .600 & 23.783 .134 & 4,42 & 0,6 & $<6$ kali & $\begin{array}{c}\text { Kurang } \\
\text { Sehat }\end{array}$ \\
\hline 2015 & 70.365 .573 & 42.568 .431 & 24.045 .086 & 3,80 & $(0,62)$ & $<6$ kali & $\begin{array}{c}\text { Kurang } \\
\text { Sehat }\end{array}$ \\
\hline 2016 & 76.274 .147 & 41.933 .173 & 21.638 .565 & 3,76 & $(0,04)$ & $<6$ kali & $\begin{array}{c}\text { Kurang } \\
\text { Sehat }\end{array}$ \\
\hline 2017 & 83.305 .925 & 43.764 .490 & 22.611 .042 & 3,94 & 0,14 & $<6$ kali & $\begin{array}{c}\text { Kurang } \\
\text { Sehat }\end{array}$ \\
\hline
\end{tabular}

Berdasarkan table diatas bahwa Working Capital turn Over PT. Gudang Garam Tbk periode 2013-2017 mengalami kenaikan pada tahun ke-1 dan mengalami penurunan di tahun ke-3 dan ke-4 akan tetapi ada kenaikan ditahun ke-5 hal ini disebabkan karena adanya penurunan pendapatan.

Tahun 2013 ketahun 2014 mengalami kenaikan sebanyak 0,6 kali dari 3,82 kali menjadi 4,42 kali. Kenaikan ini disebabkanbmeningkatnya penjualan dari tahun 2013 ke tahun 2014 sebesar Rp.55.436.954 menjadi Rp. 65.185.850.

Tahun 2014 ke tahun 2015 mengalami penurunan sebanyak 0,62 kali dari 4,42 kali menjadi 3,80 kali. Penurunan ini disebabkan meningkatnya hutang lancar dari tahun 2013 ke tahun 2014 sebesar Rp. 23.783.134 menjadi Rp. 24.045.086. 
Tahun 2015 ke tahun 2016 masih mengalami penurunan sebanyak 3,80 kali dari 3,76 kali. Penurunan ini disebabkan menurunnya aktiva lancar dari tahun 2015 ketahun 2016 sebesar Rp. 42.568.431 menjadi Rp. 41.933.173.

Tahun 2016 ketahun 2017 mengalami kenaikan kembali sebanyak 0,14 kali dari 3,76 kali menjadi 3,94 kali. Kenaikan ini disebabkan meningkatnya penjualan dari tahun 2016 ke tahun 2017 sebesar Rp.76.274.147 menjadi Rp. 83.305.925.

Working Capital turn Over

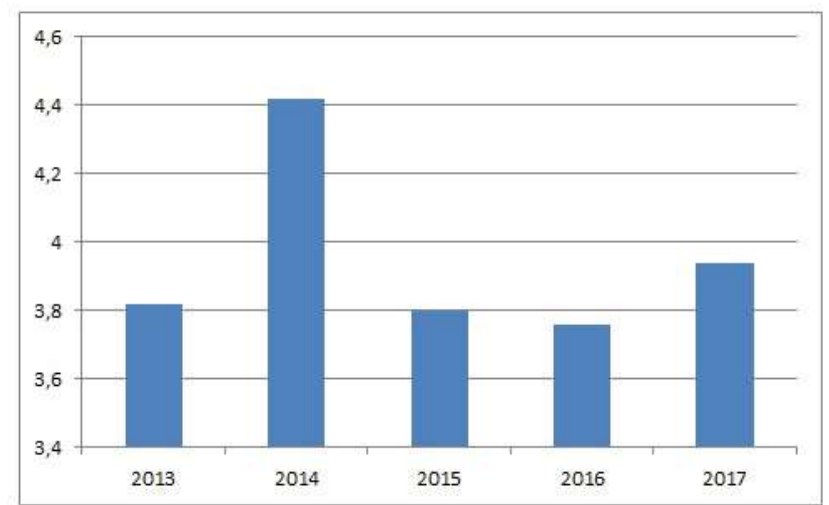

Gambar 4.1 Grafik Working Capital Turn Over

\section{b. Total Assets Turn Over}

$$
\begin{aligned}
\text { Total Assets Turn Over } & =\text { Penjualan } \\
& \text { Total Aktiva }
\end{aligned}
$$

Diperoleh perhitungan yang terlihat pada label berikut:

Table 4.2

PT. Gudang Garam Tbk

Hasil Perhitungan Total Assets Turn Over

Periode 2013/2017

\begin{tabular}{|c|c|c|c|c|c|c|}
\hline Tahun & Penjualan & $\begin{array}{c}\text { Total } \\
\text { Aktiva }\end{array}$ & $\begin{array}{c}\text { Total } \\
\text { Assets } \\
\text { TurnOver }\end{array}$ & $\begin{array}{c}\text { Naik } \\
\text { (Turun) }\end{array}$ & $\begin{array}{c}\text { Standar } \\
\text { Industri }\end{array}$ & Keterangan \\
\hline 2013 & 55.436 .954 & 50.770 .251 & 1,09 & - & $<2$ kali & Kurang sehat \\
\hline 2014 & 65.185 .850 & 58.234 .278 & 1,12 & 0,03 & $<2$ kali & Kurang sehat \\
\hline 2015 & 70.365 .573 & 63.505 .413 & 1,11 & $(0,01)$ & $<2$ kali & Kurang sehat \\
\hline 2016 & 76.274 .147 & 62.951 .634 & 1,21 & 0,1 & $<2$ kali & Kurang sehat \\
\hline 2017 & 83.305 .925 & 66.759 .930 & 1,25 & 0,04 & $<2$ kali & Kurang sehat \\
\hline
\end{tabular}

Berdasarkan table diatas terlihat bahwa Total Assets Turn Over PT. Gudang Garam Tbk periode 2013-2017 mengalami fluktuatif. Tahun 2013 ke tahun 2014 mengalami kenaikan sebanyak 0,03 kali dari1,09 kali menjadi 1,12 kali. Kenaikan ini disebabkan oleh kenaikan penjualan yang lebih besar dibandingkan 
dengan kenaikan total aktiva. Penjualan mengalami kenaikan sebesar Rp.9.748.896, sedangkan total aktiva mengalami kenaikan sebesar Rp.7.464.027.

Tahun 2014 ke tahun 2015 mengalami penurunan sebanyak 0,01 kali dari 1,12 kali menjadi 1,11 kali. Penurunan ini disebabkan oleh kenaikan total aktiva yang lebih besar dibandingkan dengan kenaikan penjualan. Total aktiva mengalami kenaikan sebesar Rp. 5.179.723, sedangkan total aktiva mengalami kenaikan sebesar Rp. 5.271.135.

Tahun 2015 ke tahun 2016 mengalami kenaikan sebanyak 0,1 kali dari 1,11 kali menjadi 1,21 kali. Kenaikan ini disebabkan oleh kenaikan penjualan dan penurunan total aktiva. Penjualan mengalami kenaikan sebesar Rp. 5.908.574, sedangkan total aktiva mengalami penurunan sebesar Rp. 553.779.

Tahun 2016 ke tahun 2017 mengalami kenaikan sebanyak 0,04 kali dari 1,21 kali menjadi 1,25 kali. Kenaikan ini disebabkan kenaikan total aktiva dan total aktiva sebesar Rp. 7.031.778 dan penjualan mengalami kenaikan sebesar Rp. 3.808.296.

Total Assets Turn Over

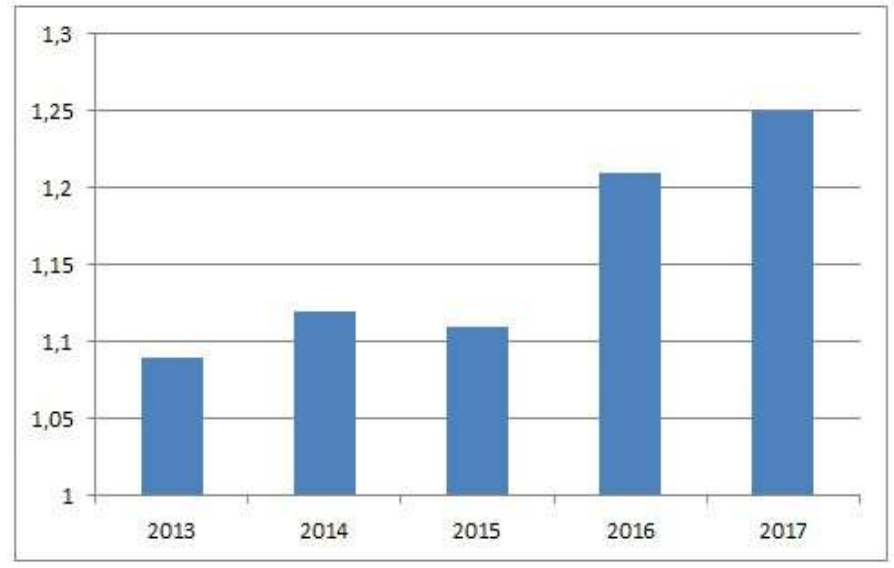

Gambar 4.2 Grafik Total assets Turn Over

2. Rasio Solvabilitas padaPT Gudang Garam Tbk periode tahun 2013-2016.

a. Debt to Assets Ratio (Debt Ratio)

Debt to Assets Ratio (Debt Ratio) = Total utang X 100\%

Total aktiva

Table 4.3

Perhitungan Debt to Assets Ratio

\begin{tabular}{|c|c|c|}
\hline Tahun & Total Hutang & Total aktiva \\
\hline 2013 & 21.353 .980 & 50.770 .251 \\
\hline 2014 & 24.991 .880 & 58.220 .600 \\
\hline 2015 & 25.497 .504 & 63.505 .413 \\
\hline 2016 & 23.387 .406 & 62.951 .634 \\
\hline 2017 & 24.572 .266 & 66.759 .930 \\
\hline
\end{tabular}

Sumber : Laporan Keuangan PT. Gudang Garam Tbk. 
Perubahan Debt toAssets Ratio

\begin{tabular}{|c|c|c|c|}
\hline Tahun & $\begin{array}{c}\text { Debt to Assets } \\
\text { Ratio }\end{array}$ & Perubahan & Keterangan \\
\hline 2013 & $42 \%$ & - & - \\
\hline 2014 & $43 \%$ & $1 \%$ & Naik \\
\hline 2015 & $40 \%$ & $-3 \%$ & Turun \\
\hline 2016 & $37 \%$ & $-3 \%$ & Turun \\
\hline 2017 & $37 \%$ & - & - \\
\hline
\end{tabular}

Sumber : Data yang diolah

Berdasarkan table 4.4 Debt to Assets Rasio PT. gudang GaramTbk terlihat bahwa:

Dari tahun 2013 ke tahun 2014 mengalami kenaikan sebesar 1\% dari 42\% menjadi $43 \%$. Hal ini disebabkan adanya kenaikan total aktiva dan total hutang.

Dari tahun 2014 ke tahun 2015 mengalami penurunan sebesar 3\% dari 43\% menjadi $40 \%$. Hal ini disebabkan adanya kenaikan pada total aktiva.

Dari tahun 2015 ke tahun 2016 mengalami penurunan sebesar 3\% dari $40 \%$ menjadi $37 \%$. Hal ini disebabkan adanya kenaikan ditahun berikutnya pada total aktiva.

Dari tahun 2016 ke tahun 2017 tidak mengalami kenaikan maupun penurunan oleh total aktiva maupun total hutang.

Maka PT. Gudang Garam Tbk harus terus mengontrol sumber pendanaan dari modal sendiri dan hutang. Dikarenakan perusahaan belum mampu mengoptimalkan asset perusahaan dan memperkecil jumlah kewajiban yang harus dibayarkan, berarti perusahaan dalam keadaan insolvable.

\section{b. Debt to Equity Ratio}

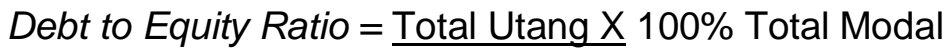

Table 4.4

Perhitungan Debt to Equity Ratio

\begin{tabular}{|c|c|c|}
\hline Tahun & Total Hutang & Ekuitas \\
\hline 2013 & 21.353 .980 & 29.416 .271 \\
\hline 2014 & 24.991 .880 & 33.228 .720 \\
\hline 2015 & 25.497 .504 & 38.007 .909 \\
\hline & 23.387 .406 & 39.564 .228 \\
\hline 20162017 & 24.572 .266 & 42.187 .664 \\
\hline
\end{tabular}

Sumber : Laporan Keuangan PT. Gudang Garam Tbk. 
Table 4.5

Perubahan Debt to equity Ratio

\begin{tabular}{|l|c|c|c|}
\hline Tahun & Debt to Equity Ratio & Perubahan & Keterangan \\
\hline 2013 & $73 \%$ & - & - \\
\hline 2014 & $75 \%$ & $4 \%$ & Naik \\
\hline 2015 & $67 \%$ & $-8 \%$ & Turun \\
\hline 2016 & $59 \%$ & $-8 \%$ & Turun \\
\hline 2017 & $58 \%$ & $-1 \%$ & Turun \\
\hline
\end{tabular}

Sumber : Data yang diolah

Berdasarkan table 4.6 Debt to Equity Ratio PT. Gudang Garam Tbk terlihat bahwa:

Dari tahun 2013 ke tahun 2014 mengalami kenaikan sebesar 4\% dari 73\% menjadi $75 \%$. Hal ini disebabkan oleh naiknya total hutang dan total ekuitas.

Dari tahun 2014 ke tahun 2015 mengalami penurunan sebesar 8\% dari 75\% menjadi $67 \%$. Hal ini disebabkan oleh meningkatnya jumlah ekuitas.

Dari tahun 2015 ke tahun 2016 kembali mengalami penurunan sebesar 8\% dari $67 \%$ menjadi $59 \%$. Hal ini disebabkan oleh kenaikan jumlah ekuitas ditahun 2015.

Tahun 2016 ke tahun 2017 mengalami penurunan kembali sebesar 1\% dari 59\% menjadi 58\%. Hal ini disebabkan oleh meningkatnya jumlah ekuitas ditahun 2017.

Maka PT. Gudang Garam Tbk harus mengontrol ekuitas atau modal sendiri dari pemilik saham sebagai sumber pendanaan perusahaan sehingga dapat terus meningkatkan nilai perusahaan.

Table 4.6

Rekapitulasi Hasil Perhitungan Rasio Solvabilitas

\begin{tabular}{|c|c|c|}
\hline Tahun & Debt ti Assets Rasio (\%) & Debt to Equity Rasio (\%) \\
\hline 2013 & $42 \%$ & $73 \%$ \\
\hline 2014 & $43 \%$ & $75 \%$ \\
\hline 2015 & $40 \%$ & $67 \%$ \\
\hline 2016 & $37 \%$ & $59 \%$ \\
\hline 2017 & $37 \%$ & $58 \%$ \\
\hline
\end{tabular}

Sumber : Data yang diolah

\section{Kinerja Keuangan PT. Gudang Garam Tbk Menurut Rasio Aktivitas dan Rasio Solvabilitas.}

\section{a. Rasio Aktivitas}

Berdasarkan perhitungan rasio aktivitas diatas, maka dapat dinilai kinerja keuangan dengan menggunakan standar pengukuran menurut Kasmir sebagai berikut: 
Tabel 4.7

Penilaian Kinerja Keuangan Berdasarkan Standar Industri PT. Gudang Garam Tbk Tahun 2013 sampai tahun 2017

\begin{tabular}{|c|c|c|}
\hline Tahun & $\begin{array}{c}\text { WCTO (Working } \\
\text { Capitan Turn Over) }\end{array}$ & $\begin{array}{c}\text { TATO (Total Assets } \\
\text { turn Over) }\end{array}$ \\
\hline 2013 & 3,82 & 1,09 \\
\hline 2014 & 4,42 & 1,12 \\
\hline 2015 & 3,80 & 1,11 \\
\hline 2016 & 3,76 & 1,21 \\
\hline 2017 & 3,94 & 1,25 \\
\hline Standar Industri & $<6$ Kali & $<2$ Kali \\
\hline Hasil & Kurang Sehat & Kurang Sehat \\
\hline
\end{tabular}

Dari hasil perhitungan rasio yang didapat dari laporan keuangan PT. Gudang Garam Tbk sehingga diketahui bagaimana kinerja keuangan perusahaan tersebut dilihat dari rasio aktivitas yaitu:

1) Working capitan turn over PT. Gudang Garam Tbk dari tahun 2013 sampai tahun 2017 adalah sebagai berikut: 3,82 kali, 4,42 kali, 3,80 kali, 3,76 kali, 3,94 kali. Menunjukkan bahwa Working capitan turnover kurang sehat karena masih di bawah rata-rata standar industry. Dimana rata-rata industry untuk working capital turnover yaitu 6 kali. Hal ini menunjukkan bahwa perusahaan sedang mengalami kelebihan modal kerja.

2) Total assets turnover PT. Gudang Garam Tbk dari tahun 2013 sampai tahun 2017 adalah sebagai berikut: 1,09 kali, 1,12 kali, 1,11 kali, 1,21 kali, 1,25 kali. Menunjukkan bahwa total assets turnover kurang sehat karena masih dibawah rata-rata industry. Dimana rata-rata industry untuk total assets turnover yaitu 2 kali. Hal ini menunjukkan bahwa perusahaan kurang efisien dalam menggunakan aktivanya dibandingkan dengan perusahaan lain.

\section{b. Rasio Solvabilitas}

Berdasarkan perhitungan rasio solvabilitas diatas, makadapat dinilai kinerja keuangan dengan menggunakan standar pengukuran menurut Kasmir dan perbandingan dengan SK Mentri Keuangan No.826/KMK.13/1992 untuk menilai kinerja keuangan PT. Gudang Garam Tbk. Berikut ini hasil kinerja keuangan berdasarkan rasio aktivitas dan rasio solvabilitas.

Table 4.8

Standar Tingkat Kesehatan Perusahaan

Berdasarkan SK Menteri Keuangan No.826/KMK.13/1992

\begin{tabular}{|c|c|c|c|c|}
\hline Tahun & $\begin{array}{c}\text { Debt ti Assets } \\
\text { Rasio (\%) }\end{array}$ & $\begin{array}{c}\text { Debt to Equity } \\
\text { Rasio (\%) }\end{array}$ & $\begin{array}{c}\text { Standar } \\
\text { Penilaian }\end{array}$ & $\begin{array}{c}\text { Hasil Penilaian } \\
\text { Kesehatan } \\
\text { Perusahaan }\end{array}$ \\
\hline 2013 & $42 \%$ & $73 \%$ & $\begin{array}{c}\text { Sehat Sekali } \\
>200 \% \\
\text { Sehat }\end{array}$ & Tidak Sehat \\
\cline { 5 - 5 } & $43 \%$ & $75 \%$ & $\begin{array}{c}\text { Tidak Sehat } \\
>150 \%-200 \%\end{array}$ & Then \\
\hline
\end{tabular}




\begin{tabular}{|c|c|c|c|c|}
\hline 2015 & $40 \%$ & $67 \%$ & \multirow{2}{*}{$\begin{array}{c}\text { Kurang Sehat } \\
>100 \%-150 \%\end{array}$} & Tidak Sehat \\
2016 & $37 \%$ & $59 \%$ & Tidak Sehat \\
2017 & $37 \%$ & $58 \%$ & $\begin{array}{c}\text { Tidak Sehat } \\
<100 \%\end{array}$ & Tidak Sehat \\
\hline
\end{tabular}

Sumber : SK Mentri Keuangan No.826/KMK.13/1992

Menurut Rasio Solvabilitas, debt to assets ratio PT. Gudang Garam Tbk di tahun 2013 tidak sehat, tahun 2014 tidak sehat, tahun 2015 tidak sehat, 2016 tidak sehat, 2017 tidak sehat dan mengalami penurunan di setiap tahunnya. Debt to Equity ratio PT. Gudang Garam Tbk di tahun 2013 tidak sehat, tahun 2014 tidak sehat, tahun 2015 tidak sehat, tahun 2016 tidak sehat, tahun 2017 tidak sehat dan mengalami penurunan di setiap tahunnya. Dapatkan dikatakan bahwa perushaan dalam keadaan invisible yaitu perushaan tidak dapat memenuhi kewajiban jangka panjangnya apabila perusahaan tersebut dilikuidasi (dibubarkan). Kinerja PT. Gudang garam Tbk masih dapat bekerja dengan baik dan masih mempunyai kesempatan atau waktu untuk memperbaiki sovabilitasnya.

\section{IV.KESIMPULAN DAN SARAN}

\section{A. Kesimpulan}

Berdasarkan hasil pembahasan pada bab-bab sebelumnya maka dapat disimpulkan bahwa:

1. Rasio Aktivitas PT. Gudang Garam Tbk. Peiode 2013 - 2017. Working Capital Turn Over pada Pt. gudang Garam Tbk selama lima tahun berturut-turut dari tahun 2013 sampai dengan tahun 2017 sebesar 3, 82 kali, 4,42 kali, 3,80 kali, 3,76 kali, 3,94 kali yang mengalami flukturatif setiap tahunnya, pada tahun 2013 ke 2014 dan pada tahun 2014 ke 2015 mengalami penurunan selama dua tahun berturut-turut sebesar 0,6 kali dan 0,62 kali. Total Assets Turn Over pada PT. Gudang Garam Tbk selama li,a tahun berturut-turut dari tahun 2013 sampai dengan 2017 sebesar 1,09 kali, 1,12 kali, 1,11 kali, 1,21 kali, 1,25 kali yang mengalami flukturatif pada setiap tahunnya,

2. Rasio Solvabilitas PT. gudang Garam Tbk periode 2013 - 2017. Debt to Assets Ratio PT. Gudang Garam Tbk selama lima tahun berturut-turut dari tahun 2013 sampai tahun 2017 sebesar 42\%, 43\%, 40\%, 37\%, 37\%. Debt to Equity Ratio PT. Gudang Garang Tbk selama lima tahun berturut-turut dari tahun 2013 sampai dengan tahun 2017 sebesar 73\%, 75\%, 67\%, 59\%, 58\% dan mengalami penurunan di setiap tahunnya

3. Kinerja keuangan PT. Gudang Garam Tbk secara keseluruhan berdasarkan dengan SK MenKeu No.826/KMK.13/1992.

a. Menurut Rasio Aktivitas, Working Capital Turn Over pada PT. Gudang Garam Tbk, selama lima tahun berturut-turut kurang sehat karena masih dibawah ratarata standar industry. Dimana rata-rata industri untuk working capital turn over yaitu 6 kali. Hal ini menunjukkan bahwa perusahaan sedang mengalami kelebihan modal kerja. Total assets turn over pada PT. Gudang Garam Tbk dari tahun 2013 sampai dengan tahun 2017 yakni kurang sehat karena masih 
dibawah rata-rata industri. Dimana rata-rata industry untuk total assets turn over yaitu 2 kali. Hal ini menunjukkan bahwa perusahaan kurang efisien dalam menggunakan aktivanya dibandingkan dengan perusahaan lain.

b. Menurut Rasio Solvabilitas, debt to assets ratio PT. Gudang Garam Tbk di tahun 2013 tidak sehat, tahun 2014 tidak sehat, tahun 2015 tidak sehat, 2016 tidak sehat, 2017 tidak sehat dan mengalami penurunan di setiap tahunnya. Debt to Equity ratio PT. Gudang Garam Tbk di tahun 2013 tidak sehat, tahun 2014 tidak sehat, tahun 2015 tidak sehat, tahun 2016 tidak sehat, tahun 2017 tidak sehat dan mengalami penurunan di setiap tahunnya. Dapatkan dikatakan bahwa perushaan dalam keadaan invisible yaitu perushaan tidak dapat memenuhi kewajiban jangka panjangnya apabila perusahaan tersebut dilikuidasi dibubarkan.

c. Kinerja PT. Gudang garam Tbk masih dapat bekerja dengan baik dan masih mempunyai kesempatan atau waktu untuk memperbaiki sovabilitasnya.

\section{B. Saran}

1. Bagi Pihak Perusahaan

Meninjau ulang posisi aktiva dan hutang lancar yang akan mempengaruhi perusahaan dalam membayar hutang-hutang jangka pendeknya dan jangka panjangnya dengan cara:

a) Transaksi-transaksi yang dapat menaikan aktiva lancar adalah menjual aktiva tetap untuk mendapatkan tambahan modal sendiri

b) Perusahaan diharapkan mampu menambah aktiva dari modal sendiri tanpa harus menambah hutang dan mampu mengurangi hutang tanpa harus menambah hutang dan mampu mengurangi hutang dan mampu mengurangi hutang tanpa harus mengurangi aktiva dengan harapan perushaan berada pada posisi likuid.

c) Lebih efektif dalam menggunakan assets yang dimiliki

d) Manajemen harus melakukan pengelolaan kas secara baik agar tidak ada kas yang idle (menganggur) dan yang akhirnya akan merugikan perusahaan.

e) Kinerja keuangan harusnya selalu ditinjau secara terus menerus agar perubahan-perubahan yang terjadi pada keuangan perusahaan agar dapat terlihat dengan jelas dan pihak manajemen dapat mengantisipasikan dan dengan cepat mengambil keputusan untuk kemungkinan-kemungkinan yang bias terjadi dimasa yang akan dating.

2. Bagi Pemegang Saham atau Salon Investor

a) Menjadikan penelitian ini bagi pemegang saham atau salon investor untuk mengetahui kinerja perusahaan, pendapatan dan keamanan investasi. Sebagai bahan pertimbangan dalam mengambil keputusan investasi.

b) Memberi kesempatan dan dukungan manajemen untuk terus berkembang sehingga memberikan peluang bisnis yang lebih baik dan membawa perusahaan kepada peringkat yang lebih baik. 


\section{DAFTAR PUSTAKA}

Hery. 2017. Analisis Laporan Keuangan. Jakarta. Penerbit PT Gramedia Widiasarana Indonesia

Sujarweni Wiratna, V. Analisis Laporan Keuangan. Yogyakarta. Penerbit:Pustaka Baru Press

Kasmir. 2015. Analisis Laporan Keuangan. Jakarta.: PT Raja Grafindo Persada

Ahmad Rodoni, Herni Ali. Manajemen Keuangan Moderen. Jakarta. Mitra Wancana Media

Brigham dan Houston. 2014. Dasar-dasar Manajemen Keuangan. Jakarta. edisi kedua, buku pertama, Penerbit:salemba Empat.

Dian Wijayanto. 2012. Pengantar Manajemen. Jakarta. PT Gramedia Pustaka Utama

Ending Winarsi, Sriyanto,dkk. 2011. Praktikum Manajemen Keuangan. Jakarta. Penerbit: Salemba Empat

Irfam Fahmi. 2011. Manajemen Kinerja Teori dan Aplikasi. Bandung. edisi kedua, buku pertama,Penerbit : Alfabela CV

Irfam fahmi. 2012. Manajemen Kinerja Keuangan. Bandung. Penernit:Alfabeta CV

Kasmir. 2012. Analisis Laporan Keuangan. Jakarta. edisi pertama, setakan kelima, Penerbit: PT.raja Grafindo Persada

Kasmir. 2012. Bank dan Lembaga Keuangan Lainnya. Jakarta. PT. Raja Grafindo Persada

Kasmir. 2010. Pengantar Manajemen Keuangan. Jakarta. Edisi pertama, cetakan kedua, Penerbit: Kencana Persada Media Group

Robbins, Stephen P. And Coulter, Mary, (2010), Management,tenth edition,Erlangga, Jakarta

Weston, J. Fred dan Copeland, Thomas E., (2009), Manajemen Keuangan, Penerjemah: A. Jaka Wasana, Binarupa Aksara, Jakarta

Husnan, Suad dan Enny Pudjiastuti, (2015), Dasar-Dasar Manajemen Keuangan, Edisi Ketujuh. Yogyakarta: UPP STIM YKPN.

Sutrisno. 2012. Manajemen Keuangan Teori, Konsep dan Aplikasi. Yogyakarta: EKONISIA.

Martono dan Agus Harjito. 2014. Manajemen Keuangan. Yogyakarta. edisi kedua, cetakan keempat,Penerbit:Ekonosia Kampus Fakultas Ekonomi UII

Harahap, Sofyan Syafri. 2015. Analisis Kritis atas Laporan Keuangan. Edisi 1-10. Jakarta: Rajawali Pers.

Hery. 2015. Analisis Laporan Keuangan. Edisi 1. Yogyakarta: Center For Academic Publishing Services

Munawir. 2007. Analisis Laporan Keuangan. Yogyakarta : Edisi Empat, Liberty. Sugiyono. (2009). Metode Penelitian Bisnis (Pendekatan Kuantitatif, Kualitatif, dan R\&D). Bandung: Alfabeta.

Prabawa Wahyu Dwian, Fitri Lukiastuti. 2015. Analisis pengaruh kinerja keuangan, manajemen risiko dan manajemen modal kerja terhadap return saham:Studi kausus pada perusahaan telekomunikasi yang listing di BEl tahun 20102013.Jakarta.Jurna Manajemen Indonesia. Vol.15-No.1.

Maith Andres Hendry.2013. analisis laporan keuangan dalam mengukur kinerja keuangan pada PT. hanjaya mandala sampoerna Tbk.Manado.Jurnal EMBA.vol. 1 No.3

www.gudanggaramtbk.com 